\title{
From biogas to biomethane: Techno-economic analysis of an anaerobic digestion power plant in a cattle/buffalo farm in central Italy
}

\author{
Ester Scotto di Perta, Elena Cervelli, Maria Pironti di Campagna, Stefania Pindozzi \\ Department of Agricultural Sciences, University of Naples Federico II, Portici (NA) Italy
}

\begin{abstract}
Anaerobic digestion (AD) is a mature technology commonly used for manure treatment, both for the stabilisation of waste and for the production of energy. The introduction of new incentives could represent an opportunity for biogas production, when the current feed-in-tariffs, which improved the financial feasibility of AD plants producing electricity will end.

This paper examines the feasibility of reconverting an existing AD biogas production plant into a biomethane production plant. The AD plant, in this case study, is a two-stage reactor situated in the centre of Italy and mainly fed with livestock manure from both cows and buffaloes. The economic analysis of two hypotheses is provided: i) continuing the electricity production from biogas after the end of the current incentives (2025); ii) considering the new incentives program for the biomethane and reconverting the plant, using hollow-fibre membranes for the purification of the raw biogas (SEPURAN ${ }^{\circledR}$ Green modules, EnviTec). For this purpose, investment and operating costs, based on plant monitoring data (2105.3 $\mathrm{m}^{3} \mathrm{~d}^{-1}$, Biogas production; $4432.9 \mathrm{kWh} \mathrm{d} \mathrm{d}^{-1}$, electricity production) as well as on market analysis for costs evaluation were considered.

The mean biogas production for the considered year was about $30 \%$ less than the expected production, indicated by producer,
\end{abstract}

Correspondence: Stefania Pindozzi, Department of Agricultural Science, University of Naples Federico II, via Università 100, 80055 Portici (NA), Italy.

E-mail: stefania.pindozzi@unina.it

Key words: Anaerobic digestion; biomethane production; incentives; livestock manure.

Acknowledgements: this research was realised under the Project RiAGRI-Sele funded by Rural Development Program for 2014 - 2020 of Campania Region. The authors would like to thank Mr Antonio Trionfi Honorati, for the possibility of carrying out the research activities on his farm and Dr Dianna Pickens, for English revision of the manuscript and prof. Cembalo for his suggestions.

Received for publication: 11 January 2019.

Accepted for publication: 20 June 2019.

(C) Copyright: the Author(s), 2019

Licensee PAGEPress, Italy

Journal of Agricultural Engineering 2019; L:939

doi:10.4081/jae.2019.939

This article is distributed under the terms of the Creative Commons Attribution Noncommercial License (by-nc 4.0) which permits any noncommercial use, distribution, and reproduction in any medium, provided the original author(s) and source are credited. highlighting the need for the optimisation of the management of the reactors. Moreover, based on the averaged methane production (June 2017-June 2018), results show that: i) plant conversion for the biomethane production is not suitable for small-scale plants, due to the high investment costs of upgrading technology (1.2 $\mathrm{M} €)$; ii) when current incentives end, the electricity production from biogas in the current plant may not be self-sufficient, due to the highly expensive operating costs.

This paper provides a first analysis of the possible fate of the biogas plants under the new incentives.

\section{Introduction}

Over the past 20 years, anaerobic digestion (AD) has gained increasing interest in Europe for treating dairy, livestock manure, and crop residues, as well as industrial and commercial wastes (Edwards et al., 2015). Usually, large-scale AD reactors are used to treat many different types of organic wastes from industrial farms and communities. Instead, small-scale digesters are commonly used in dairy farms in order to improve the manure management (Scotto di Perta et al., 2018b), both for the stabilisation of the livestock waste and for the advantage of producing renewable energy in rural farming communities, along with the reduction of odour and methane emissions (Scotto di Perta et al., 2018a).

In Italy, in 2010 alone, $20 \%$ of biogas production from biomasses belongs to agricultural and livestock residues, which could be considered as an opportunity to enlarge farmers' income and to reduce the dependency on fossil energy sources, as well as the emissions in the atmosphere (Oberti et al., 2013). Indeed, AD is a robust and largely used biochemical conversion process (Coppolecchia et al., 2015), and it is considered to be one of the most advantageous techniques for livestock manure treatment, enabling the production of biogas that could be used as a fuel for heat and electricity production (Nasir et al., 2012). Biogas mainly consists of $50-70 \%(\mathrm{v} / \mathrm{v})$ methane $\left(\mathrm{CH}_{4}\right)$ and $25-45 \%(\mathrm{v} / \mathrm{v})$ carbon dioxide $\left(\mathrm{CO}_{2}\right)$, and trace amounts of water $\left(\mathrm{H}_{2} \mathrm{O}\right)$, nitrogen $\left(\mathrm{N}_{2}\right)$, oxygen $\left(\mathrm{O}_{2}\right)$, hydrogen $\left(\mathrm{H}_{2}\right)$, ammonia $\left(\mathrm{NH}_{3}\right)$, and hydrogen sulphide $\left(\mathrm{H}_{2} \mathrm{~S}\right)$ (Akbulut, 2012).

Generally, manure has a low content of total solids: $5-7 \%$ total solids (TS) for pigs, 7-9\% TS for dairy cows (Angelidaki and Ellegaard, 2003) and 8.1-8.3\% TS for buffalo cows (Esposito et al., 2012; Scotto di Perta et al., 2019). The high content of water, together with the large fraction of hard to degrade lignocellulosic material contained in the manure is the reason for the low methane yields of manure, usually ranging from 10 to $20 \mathrm{~m}^{3}$ of $\mathrm{CH}_{4} \mathrm{t}^{-1}$ of manure treated (Angelidaki and Ellegaard, 2003). Thus, the addition of co-digestion feedstocks could enhance the overall biogas production of an AD plant by improving the degradation of substrates that are hard to digest as a single substrate (Holliger et al., 2017). Specifically, co-digested materials showed an accelerated 
apparent hydrolysis rate in comparison with the individual substrate rates (Ebner et al., 2016).

The growing interest in AD applications for livestock activities is mainly due to the production of renewable energy, the stabilisation of biomass before its agronomic use and the emission of fewer odours from livestock farms (Pantaleo et al., 2013). Indeed, in addition to the improvement in manure management, AD technology has been considered by many EU governments as a way to accomplish greenhouse gases reductions in the agriculture sector (GMI, 2014).

Nevertheless, AD technology has such high investment and operating costs that they could not be regained exclusively through common agricultural practices (Vasco-Correa et al., 2018). For this reason, the diffusion of this technology has been encouraged by policy regulations and incentives related to renewable energy production (Ariunbaatar et al., 2015), which are necessary for reducing operating costs. Currently, various incentives exist in different countries. In particular, in order to achieve new goals for biofuels in the transportation sector, European countries are now moving to other financial opportunities for these plants, providing an alternative technological option to AD plants for power production: biogas upgrading to biomethane (Budzianowski and Budzianowska, 2015). New incentives could represent an alternative to stopping biogas production when the current feed-in-tariffs (FiTs) will end.

In Italy in recent years, the number of $\mathrm{AD}$ plants for the production and transformation of biogas into electric and thermal energy from organic substrates has grown (Dinuccio et al., 2014). Specifically, the subsidies existing for energy production from biomass have given rise to new interest in biogas, creating new opportunities for the agricultural and livestock sectors (Chiumenti et al., 2009; Pantaleo et al., 2013). As a consequence, from May 2011 to December 2012 alone, the number of AD plants in Italy increased by $95 \%$, with a total installed electrical capacity of 756 MW (Fabbri et al., 2013). In the majority of cases, plants are characterised by completely stirred tank reactors (CSTR) in reinforced concrete, accounting for $57 \%$ of the total Italian plants; followed by piston-driven horizontal flow reactors $(\mathrm{PFR}=$ plug flow reactor) accounting for $23 \%$ (Piccinini et al., 2011). In the CSTR a mechanical agitation provides continuous mixing of reactor contents; instead, in the PFR feedstock flows semi-continuously from one end of the reactor to the other (Nasir et al., 2012).

A new Italian decree (Ministerial Decree of 2 March 2018) establishes the possibility for the existing plants to be converted to produce biomethane. Specifically, it provides for the withdrawal of Certificates of release for consumption (CICs) of biomethane produced emitted by the Gestore dei Servizi Energetici. The calculation of the assigned CICs and their value depends on the biomass used. In the case of advanced biomethane produced with by-products, they are withdrawn at $€ 375$ per CIC $(1 \mathrm{CIC}=10 \mathrm{Gcal}$ ) for 10 years. This paper provides a techno-economic analysis of the reconversion of an existing PFR plant, producing biogas, into a biomethane production plant, considering all the facilities related to that conversion. Firstly, a brief technical description of the operating condition of the plant is provided, followed by an economic analysis considering capital and operating costs, based on plant monitoring data as well as on market analysis for costs evaluation. For that purpose, two scenarios are considered: i) continuing the electricity production from biogas, even after the end of the incentives (2025); ii) considering the new incentives program for the biomethane and reconvert the plant, using hollow-fibre membranes for the purification of raw biogas (SEPURAN ${ }^{\circledR}$ Green modules, EnviTec) in small plants. An estimation of resulting revenues is finally provided.

\section{Materials and methods}

\section{Description of the anaerobic digestion plant}

The biogas plant, case study, is a full-scale two-stage reactor (treating mainly buffalo and cow manure), located in Jesi (Marche region, $\left.43^{\circ} 29^{\prime} 13.1^{\prime \prime} \mathrm{N}, 13^{\circ} 13^{\prime} 09.0^{\prime} \mathrm{E}\right)$, in the centre of Italy. It was installed in 2007, in order to treat the manure of the nearby dairy farm, characterised by 150 heads of cattle and 200 heads of buffalos, mainly reared in Italian southern regions (Scotto di Perta et al., 2019). It was chosen as a representative small-medium plant of Central-Southern Italy and monitored from June 2017-June 2018, in order to reveal the main performance indicators, the process stability, and the biogas production, according to the feedstock characteristics.

The AD plant (EISENMANN CORPORATION technology) treats a substrate with high dry matter content. The plant is characterised by two reactors: the digester 1 is plug-flow reactor $(270$ $\mathrm{m}^{3}$ ), in which the stirring is mechanical and the matter is forwarded by compression (Andre et al., 2018), the digester 2 is a CSTR reactor $\left(750 \mathrm{~m}^{3}\right)$. The plug-flow reactor could be a proper solution for farms, since it allows sufficient resident time for manure sanitisation and reduces the risk of inefficient short-circuiting of feedstock that can occur due to poor mixing and ensures the ideal microbiological conditions.

The average retention time is 10 days for the digester 1 and 20 days for the digester 2 , respectively. The inside temperature is approximately $43^{\circ} \mathrm{C}$. The digestate is then separated into a solid and liquid fraction. A small amount of them is recirculated in the digester 1 and the remainder is utilised to fertilise the field of the farm. The biogas produced from both reactors is normally used by the farm for the production of electricity and heat, by means of a co-generation unit with a maximum electrical power of $250 \mathrm{~kW}$. Currently, the heat produced is utilised within the farm and for heating the digesters.

\section{Substrate characterisation}

Substrate composition can change depending on the season and the availability of different materials. The AD plant, in addition to Buffalo and cow farmyard manure and slurry from the dairy farm, is fed with other co-digestion materials, such as other animal manure, energy crops, and whey from the nearby dairy factory. All input materials are crushed and mixed in a hopper and conveyed to the plug-flow reactor by means of a screw.

\section{Monitoring period}

During the period June 2017-June 2018 the AD plant was monitored in order to record the process stability, and the biogas production, according to the feedstock characteristics. Specifically, the first parameter observed was the daily load, since methane yield is mainly related to the substrate composition and proportion. Also, the biogas production $\left(\mathrm{m}^{3} \mathrm{~d}^{-1}\right)$, directly correlated with the volatile solids content, and electricity produced $\left(\mathrm{kWh} \mathrm{d}^{-1}\right)$ were recorded daily.

\section{Description of scenarios}

This information was used to provide an economic comparison, considering capital and operating costs, between two scenarios: i) continuing the electricity production from biogas, even after the end of the incentives (2025); ii) considering the new incentives program for the biomethane to reconvert the plant. 


\section{Scenario 0 (2022-2026)}

In Scenario 0, it has been supposed that the $\mathrm{AD}$ plant keeps producing and selling electricity to the national grid even after the end of FiT that is in 2025. FiTt was introduced by Ministerial Decree of 2 March 2018, establishing that the electricity produced by plants working with renewable energy can be sold to the local grid at a price of $0.28 € \mathrm{kWh}^{-1}$ (corresponding to the above-mentioned FiT) for a period of 15 years from the starting day of production that was in 2010 . Thus in 2026 , electricity produced will be sold at a price of $0.093 € \mathrm{kWh}^{-1}$, which corresponds to the minimum income foreseen by Italian Ministerial Decree 618/2013/R/EFR.

\section{Scenario 1 (2022-2031)}

In this hypothesis, the $\mathrm{AD}$ plant would be reconverted for biomethane production according to the new incentives program. In conformity with the Ministerial Decree $2 / 3 / 2018$, for a period of 10 years, the farm could sell the biomethane (BM) produced using by-products at a rate of $0.23 € \mathrm{~m}^{-3} \mathrm{BM}$. In addition, the CIC, given the whole production per year of biomethane sold by the plants, would be recognised to the farm, that could sell them at a price of $375 € \mathrm{CIC}^{-1}$.

In order to reconvert the current plant, different upgrading solutions were considered. Among them, a system for small plants was chosen. In particular, the hollow-fibre membranes has been selected for the purification of the raw biogas (SEPURAN ${ }^{\circledR}$ Green modules, EnviTec).

\section{Economic analysis}

To analyse the profitability of two hypotheses and the economic feasibility of the upgrading system, various costs and revenues components were evaluated. The investment and operating costs were discussed, based on plant operators' data as well as on the market analysis for costs evaluation. For both solutions, the economic analysis starts in 2022, which is the last year to have access to the incentives for the biomethane, which will then continue for 10 years. Following this choice, the capital cost of the existing biogas plant was not considered. Indeed, by 2022 the Pay Back Period will have already passed (Table 1). Regarding the biomethane reconversion plant, the capital costs considered are those related to the upgrading unit and to the RE.MI unit (for the biomethane regulation and measurement). The operative costs are similar for both systems, except for electricity demand, that is higher for the biomethane production. Indeed, besides the electricity demand for the AD plant operation, for the biomethane production, the electricity demand of gas compressor $\left(70 \mathrm{kWh} \mathrm{h}^{-1}\right)$ for the inlet in the natural gas supply grid, and upgrading system $\left(0.23 \mathrm{kWh} \mathrm{m}^{-3}\right.$ biogas $)$ should be considered (Table 1).

In order to compare the two hypotheses, the net present value (NPV) and the internal rate of return are used as valuation criteria. Specifically, $N P V$ is the sum of the expected net cash flows measured in today's currency (Gebrezgabher et al., 2010) (Eq 1):

$$
N P V=-C C+\sum_{t=0}^{n} \frac{C F_{t}}{(1+r)^{t}}
$$

where $C C$ is the initial capital cost, $r$ is the discount factor and $C F$ is the expected cash flow at time $t$. For both configurations, it has been assumed that the biogas and electricity production of the plant is the main value of one year of monitoring.

Generally, CF is a function of incomes related to the different systems and operating costs (Table 1). For Scenario 0, the income per year is given by Equation 2:

$$
I N C O M E_{0}=\left[\left(T_{E} * E P\right) * 365\right]
$$

where $T_{E}$ is the price of the sale of electricity produced, which corresponds to the FiT of $0.28 € \mathrm{kWh}^{-1}$ until 2025 and starting from 2026 to minimum income of $0.093 € \mathrm{kWh}^{-1}$ (Ministerial Decree $618 / 2013 / \mathrm{R} / \mathrm{EFR})$ and $E P\left(\mathrm{kWh} \mathrm{d}^{-1}\right)$ is the electrical power produced per hour.

In the case of Scenario 1, the incomes include the sale of the biomethane produced and the withdrawal of CICs (Eq 3):

$$
I N C O M E_{1}=\left[V_{C I C}+\left(T_{B} * B P\right)\right] * 365
$$

where $T_{B}$ is the price of the sale of the biomethane produced, $B P$ $\left(\mathrm{m}^{3} \mathrm{~d}^{-1}\right)$ are the volume of biomethane produced per day and $V_{C I C}$ is the value of one CIC equal to $375 €$.

Table 1. General assumption for the techno-economic assessment of biogas plant and biomethane plant, based on plant operators' data as well as on the market analysis.

\section{Biogas plant Biomethane plant}

Capital costs $-$

10

- Specific costs for the connection to the natural gas grid: 70,000€

- Costs of the gas purification unit: $35,000 €$

- Costs of upgrading system: 800,000€

- Costs of RE.MI unit (for measuring, compression): $300,000 €$

$\begin{aligned} \text { Operating costs } & \text { - Cost for feeding: } 6.1\left(€ \mathrm{q}^{-1}\right) \\ & \text { - Ordinary maintenance: } 30,000 € \\ & \text { - Extraordinary maintenance: } 10,000 € \\ & \text { - Plant electricity demand is } 6 \% \text { of the electricity production }\end{aligned}$

- Cost for feeding: $6.1\left(€ \mathrm{q}^{-1}\right)$

- Ordinary and extraordinary maintenance for upgrading system: $30,000 €$

- Ordinary and extraordinary maintenance for RE.MI unit: 18,000€

- Biogas purification (consumables): $3 € \mathrm{~kg}^{-1}$

Plant electricity demand:

- Anaerobic digestion reactors electricity demand is the same

as the regular biogas plant

- Gas compressor electricity demand: $70 \mathrm{kWh} \mathrm{h}{ }^{-1}$

- Upgrading system electricity demand: 0.23 ( $\mathrm{kWh} \mathrm{m}^{-3}$ biogas) 


\section{Results and discussion}

\section{Technical results of monitoring}

The typical composition of the substrate is summarised in Table 2. The feedstock mainly used is dairy farm slurry (483.8 $\mathrm{kgVS}_{\text {fed }} \mathrm{d}^{-1}$ ), which farm produces and needs to treat. As it is possible to observe, slurry is characterised by the lowest VS content $(5.5 \%)$, and for this reason it is added to farmyard manure $(22.4 \%$ of VS, $\left.872.3 \mathrm{kgVS}_{\text {fed }} \mathrm{d}^{-1}\right)$, horse manure $(26.3 \%$ of VS, 76.9 $\left.\mathrm{kgVS}_{\text {fed }} \mathrm{d}^{-1}\right)$ and maize silage $\left(25.3 \%\right.$ of VS, $\left.1518 \mathrm{kgVS}_{\text {fed }} \mathrm{d}^{-1}\right)$.

During the year, the composition of the substrate is variable in volatile solids (VS) content. The variation in VS content could determine a different biogas production observed during the monitoring period (Figure 1). Specifically, in the first period, which refers to the first 100 days, several reductions in production are noticeable due mainly to some technical problems of the plant. The graph shows that in the first 5 days there was a stop of production due to the opening and emptying of the second digester, an opera- tion performed about once a year to remove the sediments that have accumulated inside the digester. From day 25 to day 28 another drop in production occurred due to the failure of the mixer of the first digester and the screw for the loading of the second digester. On the day 94, due to a problem with the pump, there was no recirculation of the digestate from the second to the first digester causing a drop in production. The average productions of biogas and electricity for this period were $1649.3 \mathrm{~m}^{3} \mathrm{~d}^{-1}$ and $3665.9 \mathrm{kWh} \mathrm{d}^{-1}$, respectively. In the second period, from day 101 to day 270 , it can be observed that volatile solids load increased $\left(5181 \mathrm{kgVS}_{\text {fed }} \mathrm{d}^{-1}\right)$. Also, there was an improvement in production that remained constant throughout the period. A drop in production occurred only on day 160 due to the engine shutting down for a period of $7 \mathrm{~h}$. The average productions of biogas and electricity were $2142 \mathrm{~m}^{3} \mathrm{~d}^{-1}$ and $5022.3 \mathrm{kWh} \mathrm{d}^{-1}$, respectively.

In the third period, from day 271 to day 345 , the production was not constant due to some technical problems. The days from 272 to 276 were characterised by a drop in production due to two problems in the second digester. On days 282 to 291, there was a

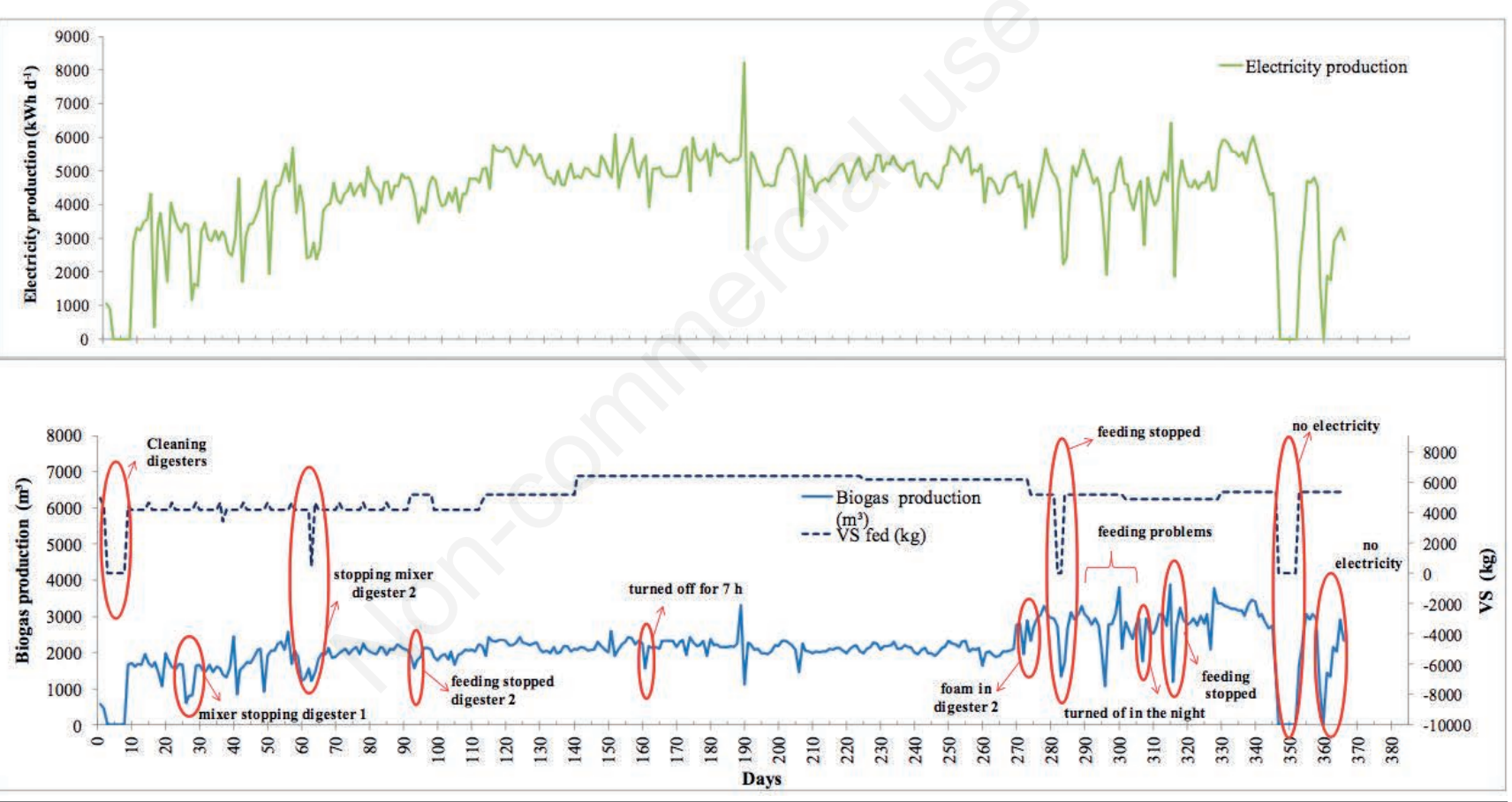

Figure 1. Electricity, Biogas production and VS fed during one year of monitoring of the given AD plant. Red circles highlight a fall in the biogas production

Table 2. Substrate composition and proportion associated with their costs, during one year of monitoring.

\begin{tabular}{|c|c|c|c|c|c|c|c|c|}
\hline & $\begin{array}{l}\text { Farmyard } \\
\text { manure* }\end{array}$ & $\begin{array}{l}\text { Dairy farm } \\
\text { slurry* }\end{array}$ & $\begin{array}{l}\text { Maize } \\
\text { silage }\end{array}$ & $\begin{array}{l}\text { Feedstock } \\
\text { Horse } \\
\text { manure }\end{array}$ & Sunflower & $\begin{array}{c}\text { Chicken } \\
\text { litter }\end{array}$ & $\begin{array}{l}\text { Rice } \\
\text { husk }\end{array}$ & $\begin{array}{c}\text { Other } \\
\text { cereal waste }\end{array}$ \\
\hline DM (\%) & 26.7 & 6.8 & 26.9 & - & 93.6 & 37.06 & 87.1 & 22.1 \\
\hline VS (\%) & 22.4 & 5.5 & 25.3 & 26.3 & 83.0 & 26.77 & 76.4 & 20.4 \\
\hline VS fed $\left(€ \mathrm{q}^{-1}\right)$ & 872.3 & 483.8 & 1518 & 76.9 & 35.7 & 62.5 & 53.2 & 95.2 \\
\hline
\end{tabular}

*Pain and Menzi (2003) classification. DM, dry matter; VS, volatile solids. 
supply block due to the breaking of the feeding auger of the first digester. The peak of day 309 is due to the night-time power failure of the plant. On days 314,315 and 316 there was a power cut due to exceeding the maximum filling level. Despite the technical problems, biogas production was higher in this period, in fact, it was $2841 \mathrm{~m}^{3} \mathrm{~d}^{-1}$ and the production of electricity was $4689.3 \mathrm{kWh}$ $\mathrm{d}^{-1}$. On day 346 the transformer of the cogeneration engine exploded due to lightning and the plant was stopped for the next 6 days. The average production of biogas for this period was $1451.6 \mathrm{~m}^{3} \mathrm{~d}^{-1}$ and the average the production of electricity was $2130.5 \mathrm{kWh} \mathrm{d}^{-1}$.

The average production of biogas for the entire period is $2105.3\left(\mathrm{~m}^{3} \mathrm{~d}^{-1}\right)$, about $29.82 \%$ less than the expected production of $3000\left(\mathrm{~m}^{3} \mathrm{~d}^{-1}\right)$, indicated by producer.

The monitoring of the performance of the $\mathrm{AD}$ plant proved to be useful insight into the management issue of a biogas plant on a farm. Specifically, the knowledge of production dynamics and average yields, during a long monitoring period, could give realistic information on the actual production yields (Piccinini et al., 2009).

In this case, it is interesting to observe how the production process could be stable in the absence of abnormal functioning of mechanical components (mixers, screws) of digesters.

Biogas production from both livestock manure and slurry is lower than other substrates, for this reason, the co-digestion with other biomass such as silage is necessary (Adani and D'Imporzano, 2008). Unfortunately, as previous studies stated (Gebrezgabher et al., 2010) the drawback of co-digestion is the cost of the feedstock, that is often the most important economic factor for the production, accounting for $121,478.40 €$ for the maize silage of the AD plant under investigation.

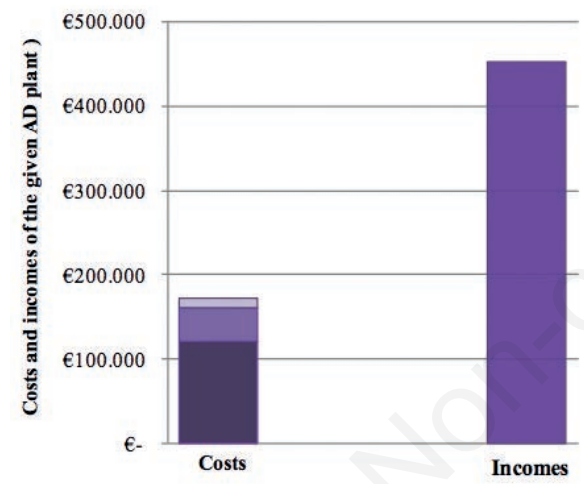

Sales of Electricity (FiT) $\square$ Electricity demand - Maintenance costs Feeding costs

\section{A}

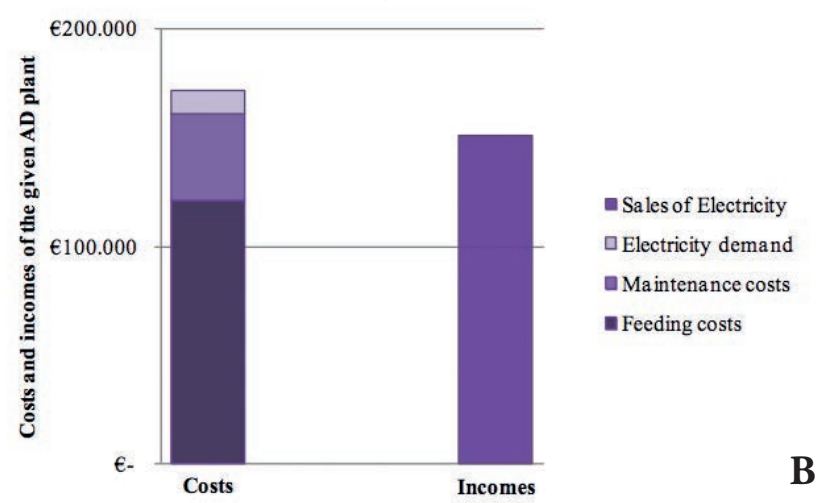

Figure 2. Economical results (based on the mean production 2017-2018) for the given $A D$ plant producing electricity from the biogas (Scenario 0): (A) with the current incentives FiT; (B) after the ending of the incentives.

\section{Economic comparison of two scenarios}

Figure 2 shows the results of the economic analysis for the AD plant in the hypothesis of keeping the electricity production from biogas (Scenario 0). Specifically,

Figure $2 \mathrm{~A}$ represents the costs and the incomes of the plant with incentives (until 2025). In this case, the revenue due to the sale of the electricity produced overcomes the costs for $281,000 €$ per year, thanks to FiT value of the sale, that allows AD being economically feasible and convenient for the farmers. Unfortunately, starting in 2025, when the tariff FiT will be abrogated, the incomes will be not sufficient for balancing the operating costs. In particular, it was observed that the cost of digester feeding accounts for about $71 \%$ of the total operating costs ( $€ 172,157.15)$.

Another interesting aspect concerns the results of the economic analysis considering the optimal biogas and electricity production. In this case, even with no subsidies, the incomes due to sales of electricity ( $€ 187,300)$ would be higher than operating costs $(€$ 174,728). Positive cash flow could justify the operation of the AD plant, even after the ending of subsidies. The biogas production could be stabilised and thus improved by reducing the plant interruption periods, mainly due to machinery malfunction. As Fabbri and Mazzetti (2012) found, small scale plants need the same biological and mechanical conditions of the biggest plants in terms of maintenance, against the profitability of the investment. Another possible solution could be reducing the operating costs related to feeding. Searching for feedstock cheaper than maize silage without reducing the VS amount inserted should be requested.

Figure $3 \mathrm{~A}$ shows the comparison between operating costs and
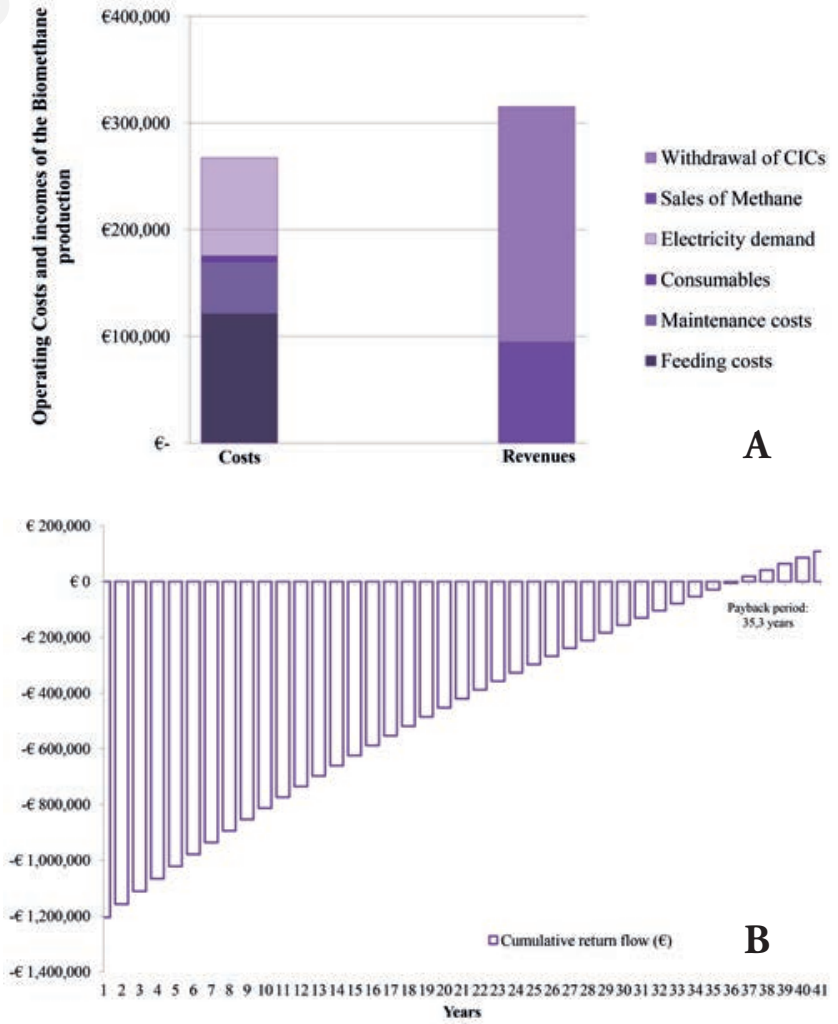

Figure 3. Economical results for the hypothesis of reconversion of the given $\mathrm{AD}$ plant for biomethane production (Scenario 1): (A) main costs and revenues (based on the mean production 20172018); (B) cumulative return flow. 
revenues of Scenario 1. In this case, the electricity demand of the plant increased up to about $34 \%$ of the total operative costs (mainly for the energy consumption of the gas compressor necessary to pump biomethane in the natural gas supply grid), whereas the feeding costs accounted for $45 \%$ of the total operative costs. In Figure $3 \mathrm{~A}$ are reported the cumulative return flow and the payback period that has been estimated to 35.3 years, assuming that after ten years (2022-2031) the incentives are still valid. This hypothesis allows realising that the capital investment costs $(€ 1,205,000)$ are too high for considering the investment convenient for the small plant as in the present study case. Indeed, considering the real period of incentives of 10 years (2022-2031), the corresponding NPV is negative $(-€ 903,473.18)$.

\section{Conclusions}

The mean biogas production for the considered year was $2105.3 \mathrm{~m}^{3} \mathrm{~d}^{-1}$, about $29.82 \%$ less than the expected production, indicated by producer. Thus, results reveal that the management of the reactors could be optimised.

The economic results showed that in the scenario without incentives the production of electricity from biogas is not advantageous due to the expensive operating costs from the extensive needs of co-digestion. As a matter of fact, the drawback of the codigestion technique is the cost of the feedstock, such as maize silage, that proved to be an important economic factor, accounting for about $71 \%$ of the total production costs. This issue could be overcome by adding other feedstocks that could improve the biogas yield or enlarging the existing plant.

According to the average values of the year, the production of biomethane is not suitable for small-scale plants. As a matter of fact, the investment costs $(1,205,000 €)$ of upgrading the technology are too high to ensure the economic viability of the biomethane project, even when the income from CICs and the sale of biomethane are considered.

\section{References}

Adani F., D'Imporzano G. 2008. I fattori che rendono ottimale la razione per il digestore. L'Inf. Agr. 40:19-24.

Akbulut A. 2012. Techno-economic analysis of electricity and heat generation from farm-scale biogas plant: Çiçekdağı case study. Energy. 44:381-90.

Andre L., Pauss A., Ribeiro T. 2018. Solid anaerobic digestion: State-of-art, scientific and technological hurdles. Bioresour. Technol. 247:1027-37.

Angelidaki I., Ellegaard, L. 2003. Codigestion of manure and organic wastes in centralised biogas plants. Appl. Biochem. Biotechnol. 109:95-105.

Ariunbaatar J., Scotto di Perta E., Panico A., Frunzo L., Esposito G., Lens P.N., Pirozzi F. 2015. Effect of ammoniacal nitrogen on one-stage and two-stage anaerobic digestion of food waste. Waste Manage. 38:388-98.

Budzianowski W.M., Budzianowska D.A. 2015. Economic analysis of biomethane and bioelectricity generation from biogas using different support schemes and plant configurations. Energy. 88:658-66.

Chiumenti R., Chiumenti A., Da Borso F., Limina S., Landa A. 2009. Anaerobic digestion of swine manure in conventional and hybrid pilot scale plants: Performance and gaseous emis- sions reduction. pp 1 in Atti del Convegno ASABE, June 21June 24, Reno, Nevada, USA.

Coppolecchia D., Gardoni D., Baldini C., Borgonovo F., Guarino M. 2015. The influence on biogas production of three slurryhandling systems in dairy farms. J. Agric. Eng. 46:30-5.

Dinuccio E., Gioelli F., Cuk D., Rollè L., Balsari P. 2014. The use of co-digested solid fraction as feedstock for biogas plants. J. Agric. Eng. 44:153-9.

Ebner J.H., Labatut R.A., Lodge J.S., Williamson A.A., Trabold T.A. 2016. Anaerobic co-digestion of commercial food waste and dairy manure: Characterising biochemical parameters and synergistic effects. Waste Manage. 52:286-94.

Edwards J., Othman M., Burn S. 2015. A review of policy drivers and barriers for the use of anaerobic digestion in Europe, the United States and Australia. Renew. Sustain. Energy Rev. 52:815-28.

Esposito G., Frunzo L., Liotta F., Panico A., Pirozzi, F. 2012. Bio-methane potential tests to measure the biogas production from the digestion and co-digestion of complex organic substrates. Open Environ. Eng. J. 5:1.

Fabbri C., Labartino N., Manfredi S., Piccinini S. 2013. Biogas, il settore è strutturato e continua a crescere. L'Inf. Agr. 11:116.

Fabbri C., Mazzetti M. 2012. Biogas medium to small sized, maintenance and essential. L'Inf. Agr. Suppl. 68:17-20.

Gebrezgabher S.A., Meuwissen M.P., Prins B.A., Lansink A.G.O. 2010. Economic analysis of anaerobic digestion - A case of Green power biogas plant in The Netherlands. NjasWagen J. Life Sci. 57:109-15.

GMI, 2014. A global prespective of anaerobic digestion policies and incentives. Global methane initiative. Available from: https://www.globalmethane.org/documents/tools/A-GlobalPerspective-of-AD-Policies-Incentives.pdf

Holliger C., Fruteau de Laclos H., Hack G. 2017. Methane production of full-scale anaerobic digestion plants calculated from substrate's biomethane potentials compares well with the one measured on-site. Front. Energy Res. 5:12.

Nasir I.M., Ghasi T.I.M., Omar R. 2012. Anaerobic digestion technology in livestock manure treatment for biogas production: a review. Eng. Life Sci. 12:258-69.

Oberti R., Tenca A., Perazzolo F., Riva E., Finzi A., Naldi E., Bodria L.C.M. 2013. A farm-scale pilot plant for biohydrogen and biomethane production by two-stage fermentation. J. Agric. Eng. 44:583-6.

Pain B., Menzi H. 2003. Glossary of terms on livestock manure management. Recycling Agricultural, Municipal and Industrial Residues in Agriculture Network (RAMIRAN). Available from: http://ramiran.uvlf.sk/DOC/Glossary 2003.pdf

Pantaleo A., De Gennaro B., Shah N. 2013. Assessment of optimal size of anaerobic co-digestion plants: an application to cattle farms in the province of Bari (Italy). Renew. Sustain. Energy Rev. 20:57-70.

Piccinini S., Fabbri C., Soldano M. 2009. Monitoring and assessment of three biogas plants in Italy. Internationale Wissenschafts. Biogas Sci. 2009:237.

Piccinini S., Soldano M., Fabbri C. 2011. La produzione di biogas del settore agricolo in Italia. Available from: https://agriregionieuropa.univpm.it/it/content/article/31/24/la-produzione-di-biogas-del-settore-agricolo-italia [In Italian].

Scotto di Perta E., Collas Y., Fiorentino N., Cervelli E., Faugno S., Pindozzi S. 2018a. Ammonia emission assessment after buffalo manure and digestate application. EurAgEng 2018 
conference from 8-12 July 2018, Wageningen, The Netherlands.

Scotto di Perta E., Fiorentino N., Gioia L., Cervelli E., Faugno S., Pindozzi S., 2019. Prolonged sampling time increases correlation between wind tunnel and integrated horizontal flux method. Agric. For. Meteorol. 265:48-55.

Scotto di Perta E., Fiorentino N., Gioia L., Faugno S., Cervelli E., Pindozzi S. 2018b. $\mathrm{NH}_{3}$ emissions from treated buffalo manure application in Mediterranean climate and comparison to ALFAM model. EurAgEng 2018 conference from 8-12 July 2018, Wageningen, The Netherlands.

Vasco-Correa J., Khanal S., Manandhar A., Shah A. 2018. Anaerobic digestion for bioenergy production: global status, environmental and techno-economic implications, and government policies. Bioresour. Technol. 247:1015-26. 